\title{
Validation and quantitative analysis of cadmium, chromium, copper, nickel, and lead in snake fruit by Inductively Coupled Plasma-Atomic Emission Spectroscopy
}

\author{
M. Tan', Sudjadi', Astuti ${ }^{2}$, Rohman ${ }^{1,2,3^{*}}$ \\ ${ }^{1}$ Faculty of Pharmacy, Universitas Gadjah Mada, Yogyakarta 55281, Indonesia. \\ ${ }^{2}$ Integrated Research and Testing Laboratory, Universitas Gadjah Mada, Yogyakarta 55281, Indonesia. \\ ${ }^{3}$ Research Centre of Halal Products, Universitas Gadjah Mada, Yogyakarta 55281, Indonesia.
}

\begin{tabular}{l}
\hline ARTICLE INFO \\
\hline Article history: \\
Received on: $12 / 10 / 2017$ \\
Accepted on: $11 / 01 / 2018$ \\
Available online: $27 / 02 / 2018$
\end{tabular}

Key words:

method validation, snake

fruit, ICP-AES, heavy

metals.

\begin{abstract}
Snake fruit or known as Salak is one of the favourite fruits and is consumed not only in Indonesia but also in the worldwide. The fruit may be contaminated with heavy toxic metals such as cadmium (Cd), chromium (Cr), copper $(\mathrm{Cu})$, nickel $(\mathrm{Ni})$, and lead $(\mathrm{Pb})$. The purpose of this study was to validate inductively coupled plasma-atomic emission spectroscopy (ICP-AES) for determination of $\mathrm{Cd}, \mathrm{Cr}, \mathrm{Cu}, \mathrm{Ni}$, and $\mathrm{Pb}$ in snake fruit. ICP-AES was validated by determining several validation parameters which included linearity and range, limit of detection and limit of quantification, precision, and accuracy. The validated method was further used for assay of these metals in snake fruit. The results showed that ICP-AES was linear over the concentration ranges of $0.025-1.0 \mu \mathrm{g} / \mathrm{mL}$ for $\mathrm{Cd}, \mathrm{Cr}$, and $\mathrm{Ni}$ and $0.050-1.0 \mu \mathrm{g} / \mathrm{mL}$ for $\mathrm{Cu}$ and $\mathrm{Pb}$, respectively. The values of coefficient of determination $\left(\mathrm{r}^{2}\right)$ obtained for these regressions were higher than 0.99 . The values of limit of detection $(\mathrm{LoD})$ of $\mathrm{Cd}, \mathrm{Cr}, \mathrm{Cu}, \mathrm{Ni}$, and $\mathrm{Pb}$ found were at $0.0010 \mu \mathrm{g} / \mathrm{mL}, 0.0024 \mu \mathrm{g} / \mathrm{mL}, 0.0047 \mu \mathrm{g} / \mathrm{mL}, 0.0037 \mu \mathrm{g} / \mathrm{mL}$, and $0.0091 \mu \mathrm{g} / \mathrm{mL}$ respectively, while limits of quantitation were of $0.0030 \mu \mathrm{g} / \mathrm{mL}(\mathrm{Cd}), 0.0073 \mu \mathrm{g} / \mathrm{mL}(\mathrm{Cr}), 0.0143 \mu \mathrm{g} / \mathrm{mL}(\mathrm{Cu}), 0.0113 \mu \mathrm{g} / \mathrm{mL}(\mathrm{Ni})$, and $0.0274 \mu \mathrm{g} /$ $\mathrm{mL}(\mathrm{Pb})$, respectively. The validated method was accurate and precise enough for determination of these heavy metals in snake fruit samples as indicated by acceptable values of recovery and low relative standard deviation (RSD) values. The developed method has been successfully used for determination of $\mathrm{Cd}, \mathrm{Cr}, \mathrm{Cu}, \mathrm{Ni}$, and $\mathrm{Pb}$ levels commercially available in the markets and farms.
\end{abstract}

\section{INTRODUCTION}

Fruits are parts of human diet sources. Snake fruit (Salacca zalacca), also locally in Indonesia known as "salak", is one of the favourite fruits for Indonesian people. "Pondoh" cultivar which originally grown in Yogyakarta province is the most popular snake fruit cultivar due to its high aroma intensity and sweetness (Supriyadi et al., 2002). Snake fruit contains various nutritional compounds such as fibers, proteins, fats, and carbohydrates and possesses high level of antioxidant (Goristein et al., 2009). Snake fruit also positively affected plasma lipid levels in cholesterol fed

${ }^{*}$ Corresponding Author

A Rohman, Integrated Research and Testing Laboratory, Universitas Gadjah Mada, Yogyakarta 55281, Indonesia.

E-mail:abdul_kimfar@ugm.ac.id rats (Leontowicz et al., 2007).

Heavy toxic metals can be accumulated in fruits with various concentrations depending on the harvesting sites of fruits (Wagner, 1993). The accumulation of the heavy metals can decline the physical health and mental cognitive of the individual (Sandeep et al., 2012). Cadmium (Cd), chromium (Cr), copper $(\mathrm{Cu})$, nickel $(\mathrm{Ni})$, and lead $(\mathrm{Pb})$ are heavy metals which are harmful for human health. Cd has toxic effects on many organs and tissues, especially on kidneys, bones, and lungs (ATSDR, 2012a). Cr may cause bad effects on gastrointestinal tract, such as abdominal pain, vomiting, peptic ulcer, hemorrhage and necrosis, and bloody diarrhea (ATSDR, 2012b). Accidental ingestion of large doses of $\mathrm{Cu}$ causes gastrointestinal bleeding, haematuria, and acute renal failure amongst other symptoms. The lower doses of $\mathrm{Cu}$ have similar effects, which caused headache, nausea, vomiting, and 
diarrhoea (Agarwal et al., 1993). Ni may cause gastrointestinal and cardiovascular disorder, liver damage, and carcinogenic effect (ATSDR, 2005). Pb nephrotoxicity is characterized by proximal tubular nephropathy, glomerular sclerosis and interstitial fibrosis (Goyer, 1989; Loghman-Adham, 1997).

Inductively coupled plasma-atomic emission spectroscopy (ICP-AES) is a method of choice for multi-elements analysis, especially for analysis of metal in trace levels. This method has some advantages over the other techniques of spectrophotometric methods, atomic absorption spectrometry, and atomic fluorescence spectrometry, namely high sensitivity (very low limit of detection), simple instrumentation, rich spectrum (more choices of spectral lines), and can analyze multiple elements at one time (Velez, 2009). The presences of $\mathrm{Cd}, \mathrm{Cr}, \mathrm{Cu}, \mathrm{Ni}$, and $\mathrm{Pb}$ in various sample such as in soil, sediment, and geological materials (Moor et al., 2001) and methanolic leaf extract (Pednekar and Raman, 2013) have been reported. However, using literature review, there was no available report related to the determination of $\mathrm{Cd}, \mathrm{Cr}, \mathrm{Cu}, \mathrm{Ni}$, and $\mathrm{Pb}$ in snake fruit. Therefore, in this study, we developed and validated fast and reliable analytical technique of Inductively Coupled PlasmaAtomic Emission Spectroscopy (ICP-AES) for quantitative analysis of $\mathrm{Cd}, \mathrm{Cr}, \mathrm{Cu}, \mathrm{Ni}$, and $\mathrm{Pb}$ in snake fruit.

\section{MATERIALS AND METHODS}

\section{Materials}

Snake fruits were collected from markets and farms in Yogyakarta, Indonesia. Cadmium (Cd), chromium (Cr), copper $(\mathrm{Cu})$, nickel $(\mathrm{Ni})$, and lead $(\mathrm{Pb})$ standard solution $(1000 \mathrm{mg} / \mathrm{L})$ was purchased from Merck (Darmstadt, Germany) in form of $\mathrm{Cd}\left(\mathrm{NO}_{3}\right)_{2}, \mathrm{Cr}\left(\mathrm{NO}_{3}\right)_{3}, \mathrm{Cu}\left(\mathrm{NO}_{3}\right)_{2}, \mathrm{Ni}\left(\mathrm{NO}_{3}\right)_{2}, \mathrm{~Pb}\left(\mathrm{NO}_{3}\right)_{2}$. Nitric acid $65 \%$ and perchloric acid $70-72 \%$ were also purchased from Merck (Darmstadt, Germany). All reagents and solvents used were pro analysis (p.a) grade. Destilled and deionized water were used as solvent. Inductively Coupled Plasma-Atomic Emission Spectrometer ICPE-9820® (Shimadzu Corp., Japan) was used for measuring the analytical response.

\section{Digestion procedure}

One kilogram of fresh snake fruit was peeled and cut into small pieces. This sample was then subjected to digestion process. Digestion procedue was carried out according to Eka et al. (2012) with slight modification. A-5 g of snake fruit sample was accurately weighed into $125 \mathrm{~mL}$ Erlenmeyer flask and added with $10 \mathrm{~mL}$ nitric acid-perchloric acid mixture in a volume ratio of $1: 1$. The mixture was subsequently heated at temperature of $110-120^{\circ} \mathrm{C}$ until the solution was clear. The sample solution was then cooled, filtered with filter paper, and diluted to $25 \mathrm{~mL}$ in volumetric flask with distilled water.

\section{Determination of $\mathrm{Cd}, \mathrm{Cr}, \mathrm{Cu}, \mathrm{Ni}$, and $\mathrm{Pb}$ using ICP-AES}

ICP-AES instrument ICPE-9820® was operated under the following conditions: radio frequency power was adjusted at $1.2 \mathrm{~kW}$, plasma gas flow at $10 \mathrm{~L} / \mathrm{min}$, auxiliary gas flow at $0.6 \mathrm{~L} /$ min, and carrier gas flow was set at $0.7 \mathrm{~L} / \mathrm{min}$. Approximately of $10.0 \mathrm{~mL}$ sample solution was introduced into sample container and analyzed at wavelength of $226.502 \mathrm{~nm}(\mathrm{Cd}), 205.552 \mathrm{~nm}(\mathrm{Cr})$, $324.754 \mathrm{~nm}(\mathrm{Cu}), 231.604 \mathrm{~nm}(\mathrm{Ni})$, and $220.353 \mathrm{~nm}(\mathrm{~Pb})$.

\section{Method validation}

Analytical method validation of ICP-AES for analysis of trace metals was assessed by determining several analytical parameters according to International Conference on Harmonization (ICH, 2005).

\section{RESULTS AND DISCUSSION}

\section{Validation of ICP-AES}

ICP-AES is method of choice for analysis of heavy metals in food and pharmaceutical products because of its low detection limits and its high degree of selectivity (Gaur et al., 2011). Before being used for quantitative analysis of heavy metals $(\mathrm{Cd}, \mathrm{Cr}, \mathrm{Cu}, \mathrm{Ni}$, and $\mathrm{Pb})$ in snake fruit, ICP-AES was validated by determining some analytical parameters, namely linearity and range, sensitivity which is expressed by limit of detection (LoD) and limit of quantitation (LoQ), precision, and accuracy. The linearity of analytical response was assessed by plotting the intensity values (y-axis) of diluted series of $\mathrm{Cd}, \mathrm{Cr}, \mathrm{Cu}, \mathrm{Ni}$, and $\mathrm{Pb}$ standard solution versus its final concentration (x-axis). The dynamic concentration ranges used were $0.025-1.000 \mu \mathrm{g} / \mathrm{mL}$ for $\mathrm{Cd}, \mathrm{Cr}$, and $\mathrm{Ni}$ and $0.050-1.000 \mu \mathrm{g} / \mathrm{mL}$ for $\mathrm{Cu}$ and $\mathrm{Pb}$. The linear relationship was established for all five regression equations with acceptable coefficient of determination $\left(r^{2}\right)$ values (Table 1). The analytical response was linear over certain concentration ranges, if the $\mathrm{r}^{2}$ value obtained is higher than 0.995 (Eurachem, 1998). Figure 1 revealed the example of releationship between concentration (x-axis) and the corresponding intensity values (y-axis) of $\mathrm{Cd}$ and $\mathrm{Cr}$. In addition, the percentage of y-intercept was low which indicated that the linear regression was free from systematic error.

Table 1: Linear regression data of cadmium, chromium, copper, nickel, and lead calibration curves.

\begin{tabular}{cccccc}
\hline Parameters & $\mathbf{C d}$ & $\mathbf{C r}$ & $\mathbf{C u}$ & $\mathbf{N i}$ & $\mathbf{P b}$ \\
\hline Linear range & $0.025-1.000 \mu \mathrm{g} / \mathrm{mL}$ & $0.025-1.000 \mu \mathrm{g} / \mathrm{mL}$ & $0.050-1.000 \mu \mathrm{g} / \mathrm{mL}$ & $0.025-1.000 \mu \mathrm{g} / \mathrm{mL}$ & $0.050-1.000 \mu \mathrm{g} / \mathrm{mL}$ \\
$\mathrm{R}^{2}$ & 0.9997 & 0.9986 & 0.9996 & 0.9963 & 0.9979 \\
Slope & 9677.8126 & 1717.9694 & 23798.1373 & 3070.7428 & 540.0743 \\
Intercept & 58.3341 & 20.5148 & 344.3711 & 13.8504 & 8.7384 \\
\% Intercept & $1.6218 \%$ & $3.1627 \%$ & $3.3750 \%$ & $1.2186 \%$ & $3.7587 \%$ \\
\hline
\end{tabular}

The analytical sensitivity of ICP-AES was evaluated by determining the values of limit of detection (LoD) and limit of quantitation (LoQ). The values of LoD and LoQ were calculated as $3.3 \mathrm{SD} / \mathrm{b}$ and $10 \mathrm{SD} / \mathrm{b}$ respectively, where $\mathrm{SD}$ is the standard deviation of analytical responses and $b$ is the slope of calibration curve. When the responses of the sample blanks 
were still high and had good precision, the sample blanks need to be diluted until its reached the lowest concentration of analyte that still showed analytical response. The values of LoD found were of $0.0010 \mu \mathrm{g} / \mathrm{mL}(\mathrm{Cd}), 0.0024 \mu \mathrm{g} / \mathrm{mL}(\mathrm{Cr}), 0.0047 \mu \mathrm{g} / \mathrm{mL}(\mathrm{Cu})$, $0.0037 \mu \mathrm{g} / \mathrm{mL}(\mathrm{Ni})$, and $0.0091 \mu \mathrm{g} / \mathrm{mL}(\mathrm{Pb})$. Meanwhile, the LoQ values found were of $0.0030 \mu \mathrm{g} / \mathrm{mL}, 0.0073 \mu \mathrm{g} / \mathrm{mL}, 0.0143 \mu \mathrm{g} /$ $\mathrm{mL}, 0.0113 \mu \mathrm{g} / \mathrm{mL}$, and $0.0274 \mu \mathrm{g} / \mathrm{mL}$ for $\mathrm{Cd}, \mathrm{Cr}, \mathrm{Cu}, \mathrm{Ni}$, and $\mathrm{Pb}$, respectively. Based on $\mathrm{LoD}$ values, ICP-AES was sensitive enough for analysis of these heavy metals because LoD values were lower than maximum values of heavy metals allowed to be present in fruit products, i.e. $0.5 \mu \mathrm{g} / \mathrm{g}$ (Roba et al., 2016).
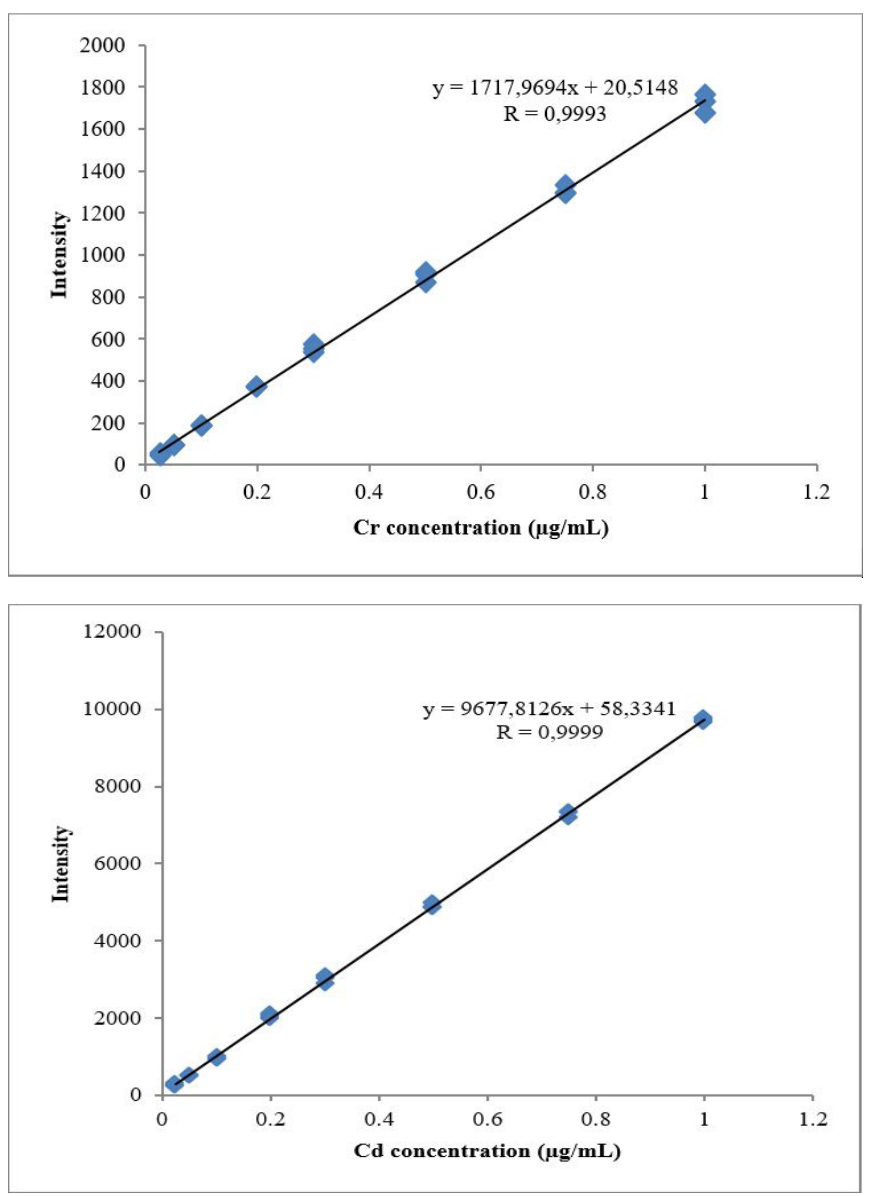

Fig. 1: The relationship between concentration (x-axis) and the corresponding intensity values (y-axis) of chromium (top) and cadmium (down).

Precision of an analytical procedure expresses the closeness of agreement (degree of scatter) between a series of measurements obtained from multiple sampling of the same homogenous sample under the prescribed conditions $(\mathrm{ICH}$, 2005). Precision is typically evaluated by measuring the values of relative standard deviation (RSD) of a set of data. The assessments were done by determining RSD under the conditions of repeatability and intermediate precision (different day of measurement). Repeatability was evaluated by measuring 10 blank sample solutions spiked with the standard solutions of $\mathrm{Cd}, \mathrm{Cr}, \mathrm{Cu}, \mathrm{Ni}$, and $\mathrm{Pb}$, each at concentration of $0.2 \mu \mathrm{g} / \mathrm{mL}$, under similar conditions (day, analyst, instrument, sample). The RSD values obtained for repeatability tests were $3.10 \%$ for $\mathrm{Cd}$,
$3.88 \%$ for $\mathrm{Cr}, 4.36 \%$ for $\mathrm{Cu}, 1.96 \%$ for $\mathrm{Ni}$, and $4.56 \%$ for $\mathrm{Pb}$. Furthermore, the same blank samples were measured again in 2 other different days to determine the intermediate precision. The RSD values obtained during the intermediate precision were $3.96 \%(\mathrm{Cd}), 6.87 \%(\mathrm{Cr}), 4.63 \%(\mathrm{Cu}), 3.56 \%(\mathrm{Ni})$, and $5.77 \%(\mathrm{~Pb})$, as shown in Table 2. According to Horwitz, the maximum RSD values acceptable for the analyte level of 1 $\mu \mathrm{g} / \mathrm{mL}$ is $16 \%$ (Gonzales and Herrador, 2007). AOAC Peer Verified Methods set the maximum acceptable RSD value at $11 \%$ for the same analyte level. Therefore, it can be stated that the ICP-AES method showed good precision based on RSD values obtained.

Table 2: The relative standard deviation (RSD) values for precision studies of ICP-AES during determination of cadmium, chromium, copper, nickel, and lead in snake fruit.

\begin{tabular}{|c|c|c|c|}
\hline \multicolumn{4}{|c|}{ Cadmium } \\
\hline \multirow[b]{2}{*}{ Day } & \multirow{2}{*}{$\begin{array}{l}\text { Calculated analyte conc. } \\
\qquad(\mu \mathrm{g} / \mathrm{mL})\end{array}$} & \multicolumn{2}{|c|}{ RSD values (\%) } \\
\hline & & Repeatability & $\begin{array}{c}\text { Intermediate pre- } \\
\text { cision }\end{array}$ \\
\hline 1 & $0.2484 \pm 0.0077$ & 3.10 & \\
\hline 3 & $0.2622 \pm 0.0078$ & 2.97 & 3.92 \\
\hline 8 & $0.2479 \pm 0.0070$ & 2.84 & \\
\hline \multicolumn{4}{|c|}{ Chromium } \\
\hline \multirow[b]{2}{*}{ Day } & \multirow{2}{*}{$\begin{array}{l}\text { Calculated analyte conc. } \\
\qquad(\mu \mathrm{g} / \mathrm{mL})\end{array}$} & \multicolumn{2}{|c|}{ RSD values (\%) } \\
\hline & & Repeatability & $\begin{array}{l}\text { Intermediate pre- } \\
\text { cision }\end{array}$ \\
\hline 1 & $0.1866 \pm 0.0072$ & 3.88 & \\
\hline 3 & $0.2060 \pm 0.0080$ & 3.88 & 6.87 \\
\hline 8 & $0.2146 \pm 0.0071$ & 3.32 & \\
\hline \multicolumn{4}{|c|}{ Copper } \\
\hline \multirow[b]{2}{*}{ Day } & \multirow{2}{*}{$\begin{array}{l}\text { Calculated analyte conc. } \\
\qquad(\mu \mathrm{g} / \mathrm{mL})\end{array}$} & \multicolumn{2}{|c|}{ RSD values (\%) } \\
\hline & & Repeatability & $\begin{array}{l}\text { Intermediate pre- } \\
\text { cision }\end{array}$ \\
\hline 1 & $0.4761 \pm 0.0208$ & 4.36 & \\
\hline 3 & $0.4820 \pm 0.0212$ & 4.40 & 4.63 \\
\hline 8 & $0.4583 \pm 0.0178$ & 3.89 & \\
\hline \multicolumn{4}{|c|}{ Nickel } \\
\hline \multirow[b]{2}{*}{ Day } & \multirow{2}{*}{$\begin{array}{l}\text { Calculated analyte conc. } \\
\qquad(\mu \mathrm{g} / \mathrm{mL})\end{array}$} & \multicolumn{2}{|c|}{ RSD values (\%) } \\
\hline & & Repeatability & $\begin{array}{l}\text { Intermediate pre- } \\
\text { cision }\end{array}$ \\
\hline 1 & $0.1979 \pm 0.0039$ & 1.96 & \\
\hline 3 & $0.2074 \pm 0.0041$ & 1.96 & 3.56 \\
\hline 8 & $0.2125 \pm 0.0043$ & 2.03 & \\
\hline \multicolumn{4}{|c|}{ Lead $(\mathrm{Pb})$} \\
\hline \multirow{2}{*}{ Day } & \multirow{2}{*}{$\begin{array}{l}\text { Calculated analyte conc. } \\
\qquad(\mu \mathrm{g} / \mathrm{mL})\end{array}$} & \multicolumn{2}{|c|}{ RSD values (\%) } \\
\hline & & Repeatability & $\begin{array}{l}\text { Intermediate pre- } \\
\text { cision }\end{array}$ \\
\hline 1 & $0.2509 \pm 0.0114$ & 4.56 & \\
\hline 3 & $0.2667 \pm 0.0142$ & 5.34 & 5.77 \\
\hline 8 & $0.2700 \pm 0.0132$ & 4.88 & \\
\hline
\end{tabular}


Table 3: The recovery values for accuracy studies of ICP-AES during determination of cadmium, chromium, copper, nickel, and lead in snake fruit.

\begin{tabular}{|c|c|c|c|}
\hline \multicolumn{4}{|c|}{ Cadmium (Cd) } \\
\hline $\begin{array}{l}\text { Actual analyte } \\
\text { conc. }(\mu \mathrm{g} / \mathrm{mL})\end{array}$ & $\begin{array}{l}\text { Calculated analyte conc. } \\
\qquad(\mu \mathrm{g} / \mathrm{mL})\end{array}$ & $\begin{array}{c}\text { Recovery percentage } \\
(\%)\end{array}$ & $\begin{array}{c}\text { RSD } \\
(\%)\end{array}$ \\
\hline 0.1 & $0.0941 \pm 0.0085$ & $94.08 \pm 8.49$ & 9.03 \\
\hline 0.2 & $0.1946 \pm 0.0042$ & $97.30 \pm 2.12$ & 2.18 \\
\hline 0.3 & $0.2883 \pm 0.0091$ & $96.08 \pm 3.02$ & 3.14 \\
\hline \multicolumn{4}{|c|}{ Chromium (Cr) } \\
\hline $\begin{array}{l}\text { Actual analyte } \\
\text { conc. }(\mu \mathrm{g} / \mathrm{mL})\end{array}$ & $\begin{array}{l}\text { Calculated analyte conc. } \\
\qquad(\mu \mathrm{g} / \mathrm{mL})\end{array}$ & $\begin{array}{c}\text { Recovery percentage } \\
(\%)\end{array}$ & $\begin{array}{l}\text { RSD } \\
(\%)\end{array}$ \\
\hline 0.1 & $0.0851 \pm 0.0045$ & $85.13 \pm 4.53$ & 5.32 \\
\hline 0.2 & $0.1876 \pm 0.0036$ & $93.80 \pm 1.82$ & 1.94 \\
\hline 0.3 & $0.2899 \pm 0.0104$ & $96.62 \pm 3.58$ & 3.58 \\
\hline \multicolumn{4}{|c|}{ Cuprum (Cu) } \\
\hline $\begin{array}{l}\text { Actual analyte } \\
\text { conc. }(\mu \mathrm{g} / \mathrm{mL})\end{array}$ & $\begin{array}{c}\text { Calculated analyte conc. } \\
(\mu \mathrm{g} / \mathrm{mL})\end{array}$ & $\begin{array}{c}\text { Recovery percentage } \\
(\%)\end{array}$ & $\begin{array}{l}\text { RSD } \\
(\%)\end{array}$ \\
\hline 0.1 & $0.0990 \pm 0.0071$ & $99.02 \pm 7.11$ & 7.18 \\
\hline 0.2 & $0.2086 \pm 0.0097$ & $104.28 \pm 4.84$ & 4.64 \\
\hline 0.3 & $0.3107 \pm 0.0097$ & $103.57 \pm 3.23$ & 3.12 \\
\hline \multicolumn{4}{|c|}{ Nickel (Ni) } \\
\hline $\begin{array}{l}\text { Actual analyte } \\
\text { conc. }(\mu \mathrm{g} / \mathrm{mL})\end{array}$ & $\begin{array}{l}\text { Calculated analyte conc. } \\
\qquad(\mu \mathrm{g} / \mathrm{mL})\end{array}$ & $\begin{array}{c}\text { Recovery percentage } \\
(\%)\end{array}$ & $\begin{array}{l}\text { RSD } \\
(\%)\end{array}$ \\
\hline 0.1 & $0.0922 \pm 0.0030$ & $92.19 \pm 3.00$ & 3.26 \\
\hline 0.2 & $0.1789 \pm 0.0015$ & $89.43 \pm 0.73$ & 0.82 \\
\hline 0.3 & $0.2762 \pm 0.0054$ & $92.08 \pm 1.80$ & 1.95 \\
\hline \multicolumn{4}{|c|}{ Timbal } \\
\hline $\begin{array}{l}\text { Actual analyte } \\
\text { conc. }(\mu \mathrm{g} / \mathrm{mL})\end{array}$ & $\begin{array}{c}\text { Calculated analyte conc. } \\
(\mu \mathrm{g} / \mathrm{mL})\end{array}$ & $\begin{array}{c}\text { Recovery percentage } \\
(\%)\end{array}$ & $\begin{array}{l}\text { RSD } \\
(\%)\end{array}$ \\
\hline 0.1 & $0.0996 \pm 0.0057$ & $99.63 \pm 5.69$ & 5.71 \\
\hline 0.2 & $0.1988 \pm 0.0040$ & $99.43 \pm 2.00$ & 2.01 \\
\hline 0.3 & $0.3021 \pm 0.0059$ & $100.71 \pm 1.96$ & 1.95 \\
\hline
\end{tabular}

Accuracy of the developed method was assessed using standard addition method and is expressed as recovery. Accuracy can determine the lack of analyte levels due to the losses or contamination during sample preparation, and matrix interferences during the measurement step (Ertas and Tezel, 2004). The recovery determination was carried out by spiking technique. Known concentration of standard solutions $(\mathrm{Cd}, \mathrm{Cr}$, $\mathrm{Cu}, \mathrm{Ni}$, and $\mathrm{Pb}$ ) were added to snake fruit, and the resulting spiked samples were measured, calculated, and compared to the known value of standard solutions added. As suggested by ICH (2005), the analytical steps were performed in three different levels of analyte concentration, with three replicates for each level of concentration. The recovery values for accuracy were shown in Table 3. According previous published study (Huber, 1998), the acceptable recovery percentage range is $80-110 \%$ for the analyte level of $1 \mu \mathrm{g} / \mathrm{mL}$. Therefore, the developed method was accurate for quantitation of $\mathrm{Cd}, \mathrm{Cr}, \mathrm{Cu}, \mathrm{Ni}$, and $\mathrm{Pb}$ in snake fruit.

\section{Determination of $\mathrm{Cd}, \mathrm{Cr}, \mathrm{Cu}, \mathrm{Ni}$, and $\mathrm{Pb}$ in snake fruit}

The levels of $\mathrm{Cd}, \mathrm{Cr}, \mathrm{Cu}, \mathrm{Ni}$, and $\mathrm{Pb}$ in some marketed snake fruit samples were quantified using the developed method. The levels of $\mathrm{Cd}, \mathrm{Cr}, \mathrm{Cu}, \mathrm{Ni}$, and $\mathrm{Pb}$ in snake fruit were shown in Table 4.The levels of $\mathrm{Cd}, \mathrm{Cr}, \mathrm{Cu}, \mathrm{Ni}$, and $\mathrm{Pb}$ from six marketed snake fruit samples were found in the range of $0.2449-0.2962 \mathrm{mg} /$ $\mathrm{kg}, 0.0658-0.1230 \mathrm{mg} / \mathrm{kg}, 0.4063-1.3982 \mathrm{mg} / \mathrm{kg}, 0.1157-0.1624$ $\mathrm{mg} / \mathrm{kg}$, and $0.4097-0.5970 \mathrm{mg} / \mathrm{kg}$, respectively.

According to Indonesian National Standard (2009), the maximum levels of $\mathrm{Cd}$ and $\mathrm{Pb}$ permissible in fruit were $0.2 \mathrm{mg} /$ $\mathrm{kg}$ and $0.5 \mathrm{mg} / \mathrm{kg}$, respectively. National Standard of the People's Republic of China (2012) set the maximum levels of $\mathrm{Cr}$ and $\mathrm{Ni}$ in foods were $0.5 \mathrm{mg} / \mathrm{kg}$ and $1.0 \mathrm{mg} / \mathrm{kg}$, respectively. Meanwhile, maximum level of $\mathrm{Cu}$ in fruit was $5 \mathrm{mg} / \mathrm{kg}$ according to Romanian Ministry of Agriculture Food and Forestry Order (Roba et al., 2016). The results showed that the levels of $\mathrm{Cr}, \mathrm{Cu}$, and $\mathrm{Ni}$ in commercially snake fruit samples were acceptable. Meanwhile, the levels of $\mathrm{Cd}$ in those snake fruit samples were higher than the level permitted by Indonesian National Standard. One of the snake fruit sample also contained unacceptable $\mathrm{Pb}$ level at 0.5970 $\mathrm{mg} / \mathrm{kg}$.

Table 4: The levels of Cadmium, chromium, copper, nickel, and lead content in marketed snake fruits.

\begin{tabular}{cccccc}
\hline Sample & $\mathbf{C d}(\mathbf{m g} / \mathbf{k g})$ & $\mathbf{C r}(\mathbf{m g} / \mathbf{k g})$ & $\mathbf{C u}(\mathbf{m g} / \mathbf{k g})$ & $\mathbf{N i}(\mathbf{m g} / \mathbf{k g})$ & $\mathbf{P b}(\mathbf{m g} / \mathbf{k g})$ \\
\hline Salak 1 & $0.2449 \pm 0.0147$ & $0.0681 \pm 0.0033$ & $0.4063 \pm 0.0554$ & $0.1242 \pm 0.0055$ & $0.4097 \pm 0.0131$ \\
& & & & & \\
Salak 2 & $0.2765 \pm 0.0054$ & $0.0814 \pm 0.0063$ & $0.6697 \pm 0.0320$ & $0.1453 \pm 0.0069$ & $0.4258 \pm 0.0214$ \\
Salak 3 & $0.2560 \pm 0.0126$ & $0.0658 \pm 0.0050$ & $1.3982 \pm 0.0464$ & $0.1157 \pm 0.0121$ & $0.4308 \pm 0.0298$ \\
Salak 4 & $0.2930 \pm 0.0127$ & $0.0879 \pm 0.0088$ & $0.9620 \pm 0.1447$ & $0.1467 \pm 0.0178$ & $0.4542 \pm 0.0340$ \\
Salak 5 & $0.2812 \pm 0.0027$ & $0.0960 \pm 0.0045$ & $0.7583 \pm 0.0374$ & $0.1456 \pm 0.0070$ & $0.4327 \pm 0.0692$ \\
Salak 6 & $0.2962 \pm 0.0137$ & $0.1230 \pm 0.0137$ & $0.7447 \pm 0.0622$ & $0.1624 \pm 0.0060$ & $0.5970 \pm 0.0093$ \\
\hline
\end{tabular}

\section{CONCLUSION}

Analytical method development of $\mathrm{Cd}, \mathrm{Cr}, \mathrm{Cu}, \mathrm{Ni}$, and $\mathrm{Pb}$ in snake fruit using ICP-AES has been developed. Evaluation of analytical method parameters including linearity, sensitivity, precision, and accuracy showed acceptable results. Furthermore, the developed method can be successfully used for determination of $\mathrm{Cd}, \mathrm{Cr}, \mathrm{Cu}, \mathrm{Ni}$, and $\mathrm{Pb}$ in snake fruits available in markets and farms. The levels of $\mathrm{Cr}, \mathrm{Cu}$, and $\mathrm{Ni}$ reported were lower than the maximum levels permitted. In 
the other hand, the levels of $\mathrm{Cd}$ in all those samples and $\mathrm{Pb}$ in one of the sample were unacceptable.

\section{ACKNOWLEDGEMENT}

The authors thank to Faculty of Pharmacy, Gadjah Mada University for financial assistance during this study. The Integrated Laboratory of Research and Testing, Gadjah Mada University (LPPT-UGM) was also acknowledged for providing facilities during this study.

\section{REFERENCES}

Agarwal, S.K., Tirwari, S.C., and Dash, S.C. Spectrum of Poisoning Requiring Hemodialysis in a Tertiary Care Hospital in India. Int. J. Artificial Organs, 1993; 16 (1): 20-22.

ATSDR. Toxological Profile for Nickel. Atlanta, USA: Agency for Toxic Substances and Disease Registry, U.S. Departement of Health and Human Service, Public Health Service, 2005.

ATSDR. Toxological Profile for Cadmium. Atlanta, USA Agency for Toxic Substances and Disease Registry, U.S. Departement of Health and Human Service, Public Health Service, 2012a.

ATSDR. Toxological Profile for Chromium. Atlanta, USA: Agency for Toxic Substances and Disease Registry, U.S. Departement of Health and Human Service, Public Health Service, 2012b.

Diamond, G.L. Risk assessment of nephrotoxic metals. In Tarloff, J. and Lash, L (eds). The toxicology of the kidney. London: CRC Press, 2005

Eka, N., Astuti, Retno, S., and Rohman, A. Validation and quantitative analysis of cadmium and lead in snake fruit by flame atomic absorption spectrophotometry. Int. Food Res. J., 2012; 19 (3): 937-940.

Ertas, O.S., and Tezel, H. A Validated Cold Vapour-AAS Method for Determining Mercury in Human Red Blood Cell. J. Pharm. Biochem. Anal., 2004; 36: 893-897.

Eurachem. The Fitness for Purpose of Analytical Method: A Laboratory Guide to Method Validation and Related Topics, 1998; Accessed on 10 January 2017 at http://www.eurachem.org/guides/pdf/ valid.pdf. 15/03/2017.

Roba C, Rosu C, Pistea I., Ozunu A, Baciu C. Heavy Metal Content in Vegetables and Fruits Cultivated in Baia Mare Mining Area (Romania) and Health Risk Assessment. Environ. Sci. Pollut. Res. Int., 2016; 23(7): 6062-6073

Gaur, S., Joshi, M.C, Saxena, S.K., and Dutt, H.K. Analytical study of water safety parameters in ground water samples of Uttarakhand in India. J. App. Pharm. Sci., 2012; 01 (09); 2011: 166-169.

Gonzalez, A.G., and Herrador, M.A. A Practical Guide to Analytical Method Validation, Including Measurement Uncertainty and Accuracy Profiles.Trends Anal. Chem., 2007; 26: 227-238.

Gorinstein, S., Haruenkit, R., Poovarodom, S., Park, Y., Vearasilp, S., Suhaj, M., Ham, K.S., Heo, B.G., Cho, J.Y., and Jang H.G.
The Comparative Characteristics of Snake and Kiwi Fruits. Food Chem. Toxicol., 2009; 47: 1884-1891.

Goyer, R.A. Mechanisms of Lead and Cadmium Nephrotoxicity. Toxicol. Lett.,1989; 46: 153-162.

Indonesian Standard Body. 2009. SNI 7387:2009. Batas Maksimum Cemaran Logam Berat dalam Pangan.

International Conference on Harmonization (ICH). Validation of Analytical Procedures: Text and Methodology Q2(R1), ICH Harmonised Tripartite Guideline, International Conference on Harmonisation of Technical Requirements for Registration of Pharmaceuticals for Human Use, Chicago, USA, 2005.

Huber L. Validation and Qualification in Analytical Laboratories, Interpharm Press, East Englewood CO, USA, 1998.

Leontowicz, M., Leontowicz, H., Drzewiecki, J., Jastrzebski, Z., Haruenkit, R., Poovaradom, S., Park, Y.S., Jung, S.T., Kang, S.G., Trakhtenberg, S., and Gorinstein, S. Two exotic fruits positively affect rat's plasma composition. Food Chem., 2007; 102: 192-200.

Loghman-Adham M. Renal effects of environmental and occupational lead exposure. Environ. Health Perspect, 1997; 105: 928-939.

Moor, C., Lymberopoulou, T., and Dietrich, V.J. Determination of Heavy Metals in Soils, Sediments and Geological Materials by ICP-AES and ICP-MS. Microchim. Acta, 2001; 136: 123-128.

National Standard of the People's Republic of China. National Food Safety Standard of Maximum Levels of Contaminants in Food (GB 2762-2012), 2012

Pednekar, P.A., and Raman, B. Multi-element Determination in methanolic Soxhlet leaf extract of Semecarpus anacardium (Linn.F.) by ICP-AES technique. Asian J. Pharm. Clin. Res., 2013; 6(suppl. 3): 1-6.

Sandeep, G., Sangita, A., Kumar, S.S., Rakhi, G., and Dinesh, K. Biological Effect of Heavy Metal in Drinking Water samples of Western Uttar Pradesh region in India. J. App. Pharm. Sci., 2012; 02 (07): 177-181.

Supriyadi, Suhardi, Suzuki, M., Yoshida, K., Muto, T., Fujita, A., and Watanabe, N. Changes in the volatile compounds and in the chemical and physical properties of snake fruit (Salacca edulis Reinw) Cv. Pondoh during maturation. J. Agric. Food Chem., 2002; 50 (26): 7627-7633.

Velez, G. Inductively Coupled Plasma: The Future of Heavy Metal Testing. Life Sci., 2009; 17: 1-2.

Wagner, G.J. Accumulation of cadmium in crop plants and its consequences to human health. Adv. Agr., 1993; 51: 173-212.

How to cite this article:

Tan M, Sudjadi, Astuti, Rohman. Validation and quantitative analysis of cadmium, chromium, copper, nickel, and lead in snake fruit by Inductively Coupled Plasma-Atomic Emission Spectroscopy. J App Pharm Sci, 2018; 8(02): 044-048. 